Portland State University

PDXScholar

\title{
Understanding the Consequences of Newcomer Proactive Behaviors: The Moderating Contextual Role of Servant Leadership
}

\author{
Talya N. Bauer \\ Portland State University, talyabauer@pdx.edu \\ Serge Perrot \\ PSL Research University \\ Robert C. Liden \\ University of Illinois at Chicago \\ Berrin Erdogan \\ Portland State University, berrine@pdx.edu
}

Follow this and additional works at: https://pdxscholar.library.pdx.edu/busadmin_fac

Part of the Industrial and Organizational Psychology Commons, and the Organizational Behavior and Theory Commons

\section{Let us know how access to this document benefits you.}

\section{Citation Details}

T.N. Bauer, S. Perrot, R.C. Liden, et al., Understanding the consequences of newcomer proactive behaviors: The moderating contextual role of servant leadership, Journal of Vocational Behavior, https://doi.org/10.1016/j.jvb.2019.05.001

This Post-Print is brought to you for free and open access. It has been accepted for inclusion in Business Faculty Publications and Presentations by an authorized administrator of PDXScholar. Please contact us if we can make this document more accessible: pdxscholar@pdx.edu. 


\section{Accepted Manuscript}

Understanding the consequences of newcomer proactive behaviors: The moderating contextual role of servant leadership

Talya N. Bauer, Serge Perrot, Robert C. Liden, Berrin Erdogan

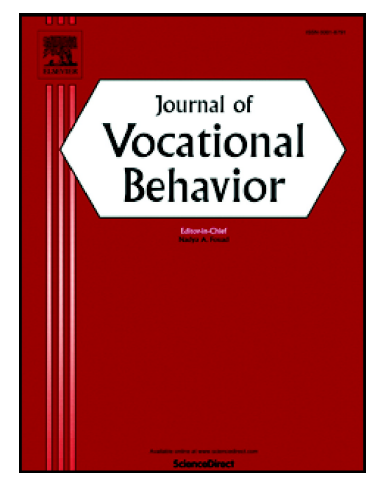

PII:

S0001-8791(19)30062-4

DOI:

https://doi.org/10.1016/j.jvb.2019.05.001

Reference:

YJVBE 3304

To appear in:

Journal of Vocational Behavior

Received date:

17 February 2017

Revised date:

2 October 2018

Accepted date:

2 May 2019

Please cite this article as: T.N. Bauer, S. Perrot, R.C. Liden, et al., Understanding the consequences of newcomer proactive behaviors: The moderating contextual role of servant leadership, Journal of Vocational Behavior, https://doi.org/10.1016/ j.jvb.2019.05.001

This is a PDF file of an unedited manuscript that has been accepted for publication. As a service to our customers we are providing this early version of the manuscript. The manuscript will undergo copyediting, typesetting, and review of the resulting proof before it is published in its final form. Please note that during the production process errors may be discovered which could affect the content, and all legal disclaimers that apply to the journal pertain. 


\title{
Understanding the Consequences of Newcomer Proactive Behaviors: The Moderating Contextual Role of Servant Leadership
}

\author{
Talya N. Bauer \\ (main point of contact) \\ Portland State University
}

Serge Perrot

PSL Research University, Paris-Dauphine

\author{
Robert C. Liden \\ University of Illinois, Chicago \\ Berrin Erdogan \\ Portland State University
}

We thank Devdeep Aikath, Eve Goldman. Rachel Mattenberger, and Danielle Garza for their help and feedback on an earlier version of this paper. 


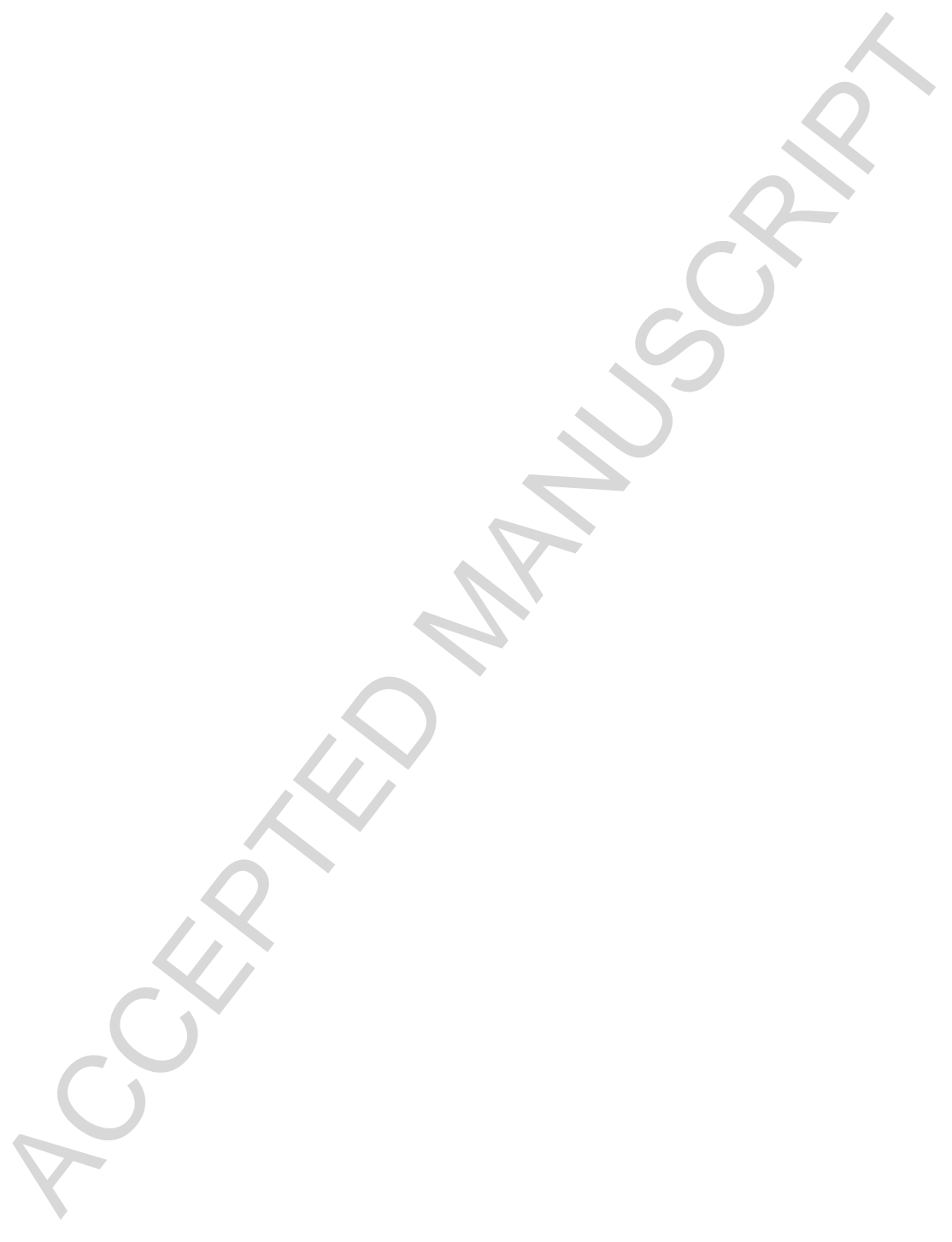


Understanding the Consequences of Newcomer Proactive Behaviors:

The Moderating Contextual Role of Servant Leadership 


\title{
Understanding the Consequences of Newcomer Proactive Behaviors: \\ The Moderating Contextual Role of Servant Leadership
}

\begin{abstract}
Proactive newcomers are more successful in terms of integration and job satisfaction, than newcomers who are less proactive. However, it is unclear whether contextual factors, such as the leadership style experienced by newcomers, matter. To address this gap in the literature, we gathered data at three times from 247 new employees across their first six months after joining a company in France. Given that past research has found that newcomers play an active role in their own adjustment process, in the current study we investigate how newcomer proactive behaviors relate to the key outcomes of job satisfaction, person-job fit, and person-organization fit. We examined the degree to which servant leadership moderated the proposed relationships. Results revealed that servant leadership generally benefited employee socialization outcomes, especially for employees low in proactive behavior. But at low levels of perceived servant leadership, followers were able to compensate for this leadership deficiency the more they engaged in proactive behaviors. Although proactive behaviors did not surpass servant leadership in relationships with job satisfaction, P-J, and P-O fit, follower proactive behaviors had the strongest relationships to these outcomes under conditions of low servant leadership.

Specifically, the results suggest that newcomer engagement in proactive behaviors is especially important to newcomer adjustment when leaders exhibit low levels of servant leadership.
\end{abstract}


Understanding the Consequences of Newcomer Proactive Behaviors:

The Moderating Role of Servant Leadership

Job transitions can be a challenging and stressful time for new employees due to uncertainty given the limited organizational knowledge and anxiety surrounding success (Ellis et al., 2015; Saks \& Ashforth, 1997). Job transitions are becoming increasingly more common, with the average U.S. employee undergoing 11.7 job transitions in his or her lifetime (Bureau of Labor Statistics, 2015). Similar trends prevail in Europe. In France, the average turnover rate increased five-fold over the last 30 years (Institut National de la Statistique et des Etudes Economiques, 2014). These trends underscore the importance of understanding the process of organizational socialization, which is a period of moving from being an organizational outsider to becoming an insider. As Wanberg (2012, p. 17) noted, “organizational socialization is about new beginnings - individuals starting new jobs within an organizational context”.

Originally, research on organizational socialization began by focusing on organizational socialization tactics organizations might employ to help newcomers adjust to their new way of organizational life (Van Maanen \& Schein, 1979). Over time, however, arguments that the socialization process is reciprocal with organizations influencing newcomers and newcomers shaping their own destinies became commonplace (e.g., Bauer \& Green, 1994; Jones, 1983; Morrison, 1993; Reichers, 1987). This view, and associated findings, was developed in parallel with work by Bateman and Crant (1993), who created and validated a measure of proactive personality. They found that those with higher proactivity scores engaged in more extracurricular and civic activities, indicating that behavior in a variety of contexts is related to individual levels of proactivity. Saks et al. (2011) contend that newcomer proactive behaviors, such as information 
seeking, relationship building, general socializing and feedback seeking help newcomers to become more equipped, efficient and self-motivated employees.

There is a current lack of understanding around whether contextual factors exist that may relate to the relationships between newcomer proactive behavior and important socialization outcomes. One key aspect of the context is the role that organizational insiders - those already established within the organization - play in newcomer socialization, with immediate supervisors being especially influential insiders. By examining newcomer proactivity within the context of support from leaders, we attempt to make two specific contributions to the literature. First, we seek to expand our understanding of the context in which key newcomer proactive behaviors matter, and to what extent. By examining the moderating role of servant leadership, we strive to better understand newcomer proactive behaviors as being useful for a newcomer's own adjustment. This is an important step toward identifying both the consequences and important boundary conditions of proactive behavior salience during socialization. One leadership approach that appears to be particularly well suited for helping newcomers adjust to new jobs, relationships, and work environments, is servant leadership. Servant leadership shows great potential for assisting newcomers during socialization, given that it is a follower-centered leadership approach. The premise behind servant leadership is the prioritization of fulfilling follower needs over the leader's own needs (Greenleaf, 1970; van Dierendonck, 2011). Metaanalytic results have shown that servant leadership explains more variance in key individual outcomes than transformational, ethical, and authentic leadership (Hoch, Bommer, Dulebohn, \& Wu, 2018). Servant leaders provide support and create an environment designed to help employees be successful and weather setbacks without giving up on their goals (Liden, Wayne, Liao, \& Meuser, 2014). Servant leaders encourage work environments that build the personal 
and professional well-being of employees by promoting their engagement in proactive behaviors (van Dierendonck, 2011). Given that "a servant leader works toward building a learning organization where each individual can be of unique value,” (van Dierendonck, 2011, p. 1231) we contend that servant leadership enables newcomers to feel confident in their ability to shape their own environment.

Second, servant leaders endeavor to help their followers achieve success and feel good about their roles. More specifically, their focus is on "developing employees to their fullest potential in the areas of task effectiveness, community stewardship, self-motivation, and future leadership capabilities" (Liden et al., 2008, p. 162). Given this, we wanted to focus on key newcomer outcomes that are personal in nature. Thus, we address how newcomer proactive behavior relates to newcomer perceptions of job satisfaction, as well as person-job (P-J) and person-organization (P-O) fit. By focusing on these outcomes, we add to the expanding proactive behavior and organizational socialization outcome literatures.

\section{Hypothesis Development}

Figure 1 depicts our theoretical model. We hypothesize that the relationships between four key newcomer proactive behaviors, which we examine as a set (information seeking, feedback seeking, general socializing, and relationship building), and the personal newcomer outcomes (job satisfaction, person-job fit, and person-organization fit), differ depending upon the level of servant leadership newcomers experience in their jobs.

\section{The Moderating Role of Servant Leadership on Proactive Behaviors and Job Satisfaction}

Research on newcomer social integration has identified two main factors that determine the ultimate adjustment of newcomers: 1) Actions taken by organizations to influence and shape newcomer adjustment; and 2) Newcomers' proactive efforts to define their roles within 
organizations (Ashford \& Black, 1996; Cable et al., 2013). Both employee proactivity and servant leadership serve as approaches to a newcomer's transition and integration into a new work environment. Meta-analytic research finds that successful employee social integration is positively related to commitment, job satisfaction, intention to remain with the organization, and job performance (Bauer et al., 2007). Proactive behaviors such as information seeking, feedback seeking, general socializing and relationship building create autonomy in a newcomer by creating a more equipped, efficient and self-motivated employee, smoothing their transition into a new work environment (Yu \& Davis, 2016).

In the current investigation, we focus on a specific set of proactive behaviors newcomers may use to facilitate their own adjustment. Research has shown that the more new employees engage in proactive behaviors, the more successful they are in adjusting to their organizations and the more positive their outcomes (see Bauer, Bodner, Erdogan, Truxillo, \& Tucker, 2007; Saks, Uggerslev, \& Fassina, 2007 for reviews). We contend that newcomers who engage in proactive behaviors are expected to experience higher levels of adjustment outcomes in the form of job satisfaction, P-J fit, and P-O fit, because they are at an advantage with respect to learning and adjusting to their new jobs. As a result, they are better positioned to reduce their anxiety, which often accompanies organizational transitions (Ellis et al., 2015). "Job satisfaction may be defined as a pleasurable or positive emotional state resulting from the appraisal of one's job or job experiences." (Locke, 1976, p. 1300). It has been consistently demonstrated that intrinsic job experiences, such as finding one's work meaningful to oneself or others enhances job satisfaction (Hackman \& Oldham, 1975). Proactive employees are inclined to identify and engage in behaviors that fulfill their need for meaning in their work, which in turn results in higher levels of job satisfaction than is experienced by less proactive employees (Tornau \& Frese, 2013). And 
the more they are able to fulfill their need to be proactive, the better they will perceive that they fit with their jobs and with the organization (Kim, Cable, \& Kim, 2005).

Further, we reason that learning how to perform their jobs more quickly allows them to be accepted among organizational insiders, which contributes to employee satisfaction and the sense that they are fitting in. Perrot, Bauer, Abonneau, Campoy, Erdogan, and Liden (2014) reported that, for the 103 blue-collar apprentices they studied in France using a time-lagged design, the relationship between organizational socialization tactics and learning on the job was moderated by perceived organizational support. However, these researchers did not examine moderating relationships for proactive behavior. Because immediate leaders are viewed by employees as representing the organization (Liden, Bauer, \& Erdogan, 2004), and perceptions of leader support drive perceptions of organizational support (Eisenberger, Stinglhamber, Vandenberghe, Sucharski, \& Rhoades, 2002), we reason that leadership moderates the relationships between newcomer proactive behaviors and socialization outcomes.

Servant leadership is a leadership approach in which the main focus of supervisors is on the wellbeing of their employees (Liden, Wayne et al., 2014; Panaccio, Donia, Saint-Michel, \& Liden, 2015). These leaders provide a psychologically safe environment (Schaubroeck, Lam, \& Peng, 2011) that values the unique qualities of their employees and strives to bring out the full potential in all followers, which in turn enhances long-term career success (van Dierendonck, 2011). The goals of a servant leader are to develop an employee to the fullest in personal areas including task effectiveness and self-motivation, as well as building community stewardship, which incorporates proactive behaviors to create and build relationships that can lead to future progress (Liden et al., 2008). Thus, it is a meaningful factor to examine in the context of newcomer proactive behaviors and socialization. 
Servant leaders provide coaching, resources and support designed to enhance employees’ personal growth and development, as well as a safe environment in which to learn from mistakes (Liden, Panaccio et al., 2014). Because self-initiated proactive behaviors and assistance provided by servant leaders provide similar benefits to newcomers, our contention is that they may substitute for each other. This means, that in instances in which servant leadership is high, there is less need for proactivity, because the employee feels supported by their employer, allowing for integration and high job satisfaction. In situations in which there is low servant leadership, employees have more responsibility to adjust to new work environments on their own, and take on the task of integration themselves through utilizing proactive behaviors. In this scenario, individuals do not wait for things to happen to them, they make things happen, and when they see the positive results of their actions, their job satisfaction increases (Crant, 2000).

Hypotheses 1a-1d: Servant leadership moderates the relationship between a set of key newcomer proactive behaviors including information seeking, feedback seeking, general socializing and relationship building, and newcomer job satisfaction, such that proactive behaviors are more strongly and positively related to job satisfaction when servant leadership is low, whereas there is a weaker positive relationship between them when servant leadership is high.

\section{The Moderating Role of Servant Leadership on Proactive Behaviors and P-J Fit}

The concept of person-job (P-J) fit refers to the overall match between the person and the job. P-J fit takes two major forms (Kristof-Brown, Zimmerman, \& Johnson, 2005): The match between the person's capabilities and job demands is referred to as demands-abilities fit, whereas the match between the person's needs and the types of rewards and opportunities the job offers is referred to as needs-supplies fit. Our approach drew upon both of these types of fit. When 
servant leadership is high, people find their jobs more aligned with what they value in a job, due to the priority the leader places on providing encouragement and support to bring out the full potential of each follower. Servant leadership consists of dimensions including empowering, helping subordinates grow and succeed, and putting subordinates first (Liden et al., 2008). For new employees experiencing this leadership, the job is more likely to meet their needs, resulting in proactive behaviors that are less important for the newcomer's perception of person-job fit. Whereas, in a scenario with lower levels of servant leadership, employees need to be proactive in order to achieve fit with the job. New employees seek information to ensure that the job fits their needs. They also seek feedback of other employees and supervisors to learn ways in which they can enhance their person-job fit. Yu and Davis (2016) note a distinction in that feedback seeking refers to newcomers proactively seeking information regarding their job performance, whereas information seeking generally refers to newcomers actively researching organizational policies and procedures (Yu \& Davis, 2016). General socializing refers to employees building relationships with their overall social environment within the organization (Yu \& Davis), which facilitates a sense of comfort within the workplace.

Hypotheses 2a-2d: Servant leadership moderates the relationship between key newcomer proactive behaviors including information seeking, feedback seeking, general socializing and relationship building, and newcomer perceptions of person-job fit, such that proactive behaviors are more strongly and positively related to P-J fit when servant leadership is low, whereas there is a weaker positive relationship between them when servant leadership is high.

\section{The Moderating Role of Servant Leadership on Proactive Behaviors and P-O Fit}

An employee's perception of person-organization (P-O) fit is a subjective belief about how well one's personal values match an organization's culture (Kristof, 1996). Employee P-O fit 
perceptions are linked to the organization's culture to the extent that they ensure the continuity of central values to provide new employees with a framework and support for responding to their work environment and for coordinating with other employees. Proactive newcomer behaviors may be helpful for achieving a sense of fit with the organization, because employees who display proactive behaviors may develop relationships with others, understand the organization's culture better, and develop the feeling that they fit with the organization. At the same time, servant leadership may provide some of the same benefits. Servant leadership emphasizes the "ideal service in the leader-follower relationship" (van Dierendonck, 2011). For these reasons, with a strong servant leader in place, proactive newcomer behavior is less important in creating the positive perceptions of $\mathrm{P}-\mathrm{O}$ fit of the employee. However, in a scenario where servant leadership is not present, proactive behaviors are substituted to integrate new employees into the organization in a way that they feel connected to their work environment.

A leading factor in greater P-O fit is the ability of the organization to reduce ambiguity for its employees. Ambiguity regarding an organization's values, structure, and the role of an employee creates disconnect between new employees and their organization. Servant leaders create a work experience, in which, employees know their roles and have room to learn and increase productivity. However, in a situation where there is an absence of servant leadership, employees need to utilize proactive behavior to reduce ambiguity in their work environment. Information seeking and feedback seeking are both behaviors through which new employees learn about their organization and its expectations of them. General socializing and relationship building are ways to integrate into the organization in a personal manner, allowing employees to adjust to their new environment and create higher P-O fit perceptions. As Kim et al. (2005) note, employees who are able to proactively develop strong relationships with their leaders, essentially 
replace institutionalized socialization tactics.

Hypotheses 3a-3d: Servant leadership moderates the relationship between a key set newcomer proactive behaviors including information seeking, feedback seeking, general socializing, and relationship building and newcomer perceptions of person-organization fit, such that proactive behaviors are more strongly and positively related to P-O fit when servant leadership is low, whereas there is a weaker positive relationship between them when servant leadership is high.

\section{Method}

\section{Sample and Procedures}

We obtained agreement from the corporate HR Director of a major French insurance company to conduct this research with their new employees. The HR Department sent new employees an email to inform them about our research one month after they started their jobs.

Once new employees received the email from the HR Department, we followed up with an email inviting them to complete a questionnaire, while guaranteeing anonymity.

Following a common set of data points in new employee research as noted by Allen, Eby, Chao, and Bauer (2017), our first survey (Time 1) was administered one month after the newcomers started their jobs. Our second survey (Time 2) was given at three months after entry. Our final survey (Time 3) was administered at six months after entry. Of the 649 new employees we invited to participate in our study, 378 completed our survey at Time 1 providing information regarding their demographics. At Time 2, 344 of these new employees completed our survey, reporting servant leadership and proactive behaviors. Finally, at Time 3, 353 of the new employees completed our survey, reporting job satisfaction, person-job, and person-organization 
fit. Study variables were collected using T2 and T3 surveys. This led to an overall response rate of $38 \%$ (247 out of 649) for the matched questionnaires.

In order to examine whether respondents differed from nonrespondents with respect to study variables, we ran $t$-tests comparing those in our sample with others we had to drop because they responded to only one survey. These analyses showed that respondents did not differ from nonrespondents regarding feedback seeking, relationship building, general socialization, perceived servant leadership, P-J fit, P-O fit, or job satisfaction. The only significant difference was in information seeking, with respondents reporting slightly higher levels of information seeking (mean difference $=.13, t=2.07, p<.05)$.

Our final matched sample of $62 \%$ female, was on average 25.91 years old $(\mathrm{SD}=6.66)$, and reported having an average of 5.31 years $(\mathrm{SD}=7.23)$ of previous work experience outside the company. In terms of education, the sample consisted of $18 \%$ employees at high school level or less, $51 \%$ with 2 to 3 years of education after high school, and $31 \%$ had more than 3 years of education after high school.

\section{Measures}

We used established scales. All study scales were translated from English to French by one of the authors using a back translation procedure recommended by Brislin (1970). We used a 5point Likert scale $(1=$ strongly disagree to $5=$ strongly agree $)$ for all the measures in this study. Alphas are reported for the final matched sample.

Newcomer proactive behaviors. For this study, we chose to assess four specific newcomer proactive behaviors from Ashford and Black's (1996) proactive behavior scale. Information seeking and feedback seeking were measured using four items each. General socializing and relationship building with the leader were measured using three items each. Sample items include, 
"I tried to learn the important policies and procedures in the organization" (information seeking, $\alpha$ $=.86$ ), "I sought out feedback on my performance during assignments" (feedback seeking, $\alpha=$ .91), "I attended company social gathering" (general socializing, $\alpha=.75$ ), and "I tried to form a good relationship with my boss" (relationship building with manager, $\alpha=.67$ ).

Servant leadership. We used the 28-item servant leadership scale developed by Liden et al. (2008). Higher-order CFAs have shown that the 7 dimensions assessed with this scale load onto a second-order factor capturing overall/global servant leadership (Chiniara \& Bentein, 2018; Hu \& Liden, 2011). A sample item is, "My manager provides me with work experiences that enable me to develop new skills" $(\alpha=.92)$.

Job satisfaction. We used Hackman and Oldham's (1975) job satisfaction scale consisting of three items. A sample item is, "Generally speaking, I'm very satisfied with this job" $(\alpha=.83)$.

Fit. For person-job fit, we adapted Saks and Ashforth's (1997) four items so that they can be answered using a strongly disagree - strongly agree Likert scale. A sample item is, "The job fulfills my needs" $(\alpha=$.92). For person-organization fit, we adapted Saks and Ashforth's (1997) four items so that they can be answered using a strongly disagree - strongly agree Likert scale. A sample item is, "The values of the organization are similar to my own values" $(\alpha=.90)$.

\section{Results}

Means, standard deviations, and intercorrelations among variables are presented in Table 1. Among the correlations, it is noteworthy that servant leadership was positively related to all four proactive behaviors. Also, observation of simple correlations reveals that information seeking, general socializing, and relationship building were positively related to all three outcome variables. Feedback seeking, however, was only related to job satisfaction. Our review of the correlations revealed moderate to high correlations among some study variables. Specifically, 
servant leadership and relationship building were correlated at .45. Job satisfaction was correlated with P-J fit and P-O fit at .76 and .64 respectively, and the correlation between P-J and P-O fit was .69. In order to examine whether employees were able to distinguish between these theoretically related constructs, we conducted a confirmatory analysis. Items were treated as indicators of each latent variable except for servant leadership. Servant leadership consisted of 28 items representing seven dimensions. Therefore, we treated each dimension as the indicator, resulting in seven indicators for this variable.

The original model including all study variables fit the data well $\left(\chi^{2}=1160.21, \mathrm{df}=436\right.$, $\mathrm{CFA}=.90, \mathrm{RMSEA}=.06)$. Further, alternative models where servant leadership and relationship development $\left(\Delta \chi^{2}(7)=125.38, p<.01\right)$, job satisfaction and P-J fit $\left(\Delta \chi^{2}(7)=\right.$ 111.90, $p<.01)$, job satisfaction and P-O fit $\left(\Delta \chi^{2}(7)=149.20, p<.01\right)$, and P-J fit and P-O fit $\left(\Delta \chi^{2}(7)=370.65, p<.01\right)$ were treated as a single factor resulted in worse fit to the data. These analyses provided support for treating our study variables as distinct.

We used the Process macro developed by Hayes (2013) to test our hypotheses. Tables 2-5 summarize the moderation analysis results along with bootstrapped confidence intervals and conditional effects at low (1SD below the mean), mean, and high levels of the moderator (1SD above the mean). Consistent with Hypothesis 1, results presented in Tables 2, 3, 4, and 5 show that the interaction term of all four newcomer proactive behaviors with servant leadership were significant with respect to job satisfaction. The plots presented in Figures $2 \mathrm{a}, 2 \mathrm{~b}, 2 \mathrm{c}$, and $2 \mathrm{~d}$ illustrate the nature of the interaction at one standard deviation above and below the mean. Conditional effects showed that at high levels of servant leadership, there was no significant relationship between information seeking $(b=.04, t=.39, p>.05)$, feedback seeking $(b=-.11, t$ $=-1.32, p>.05)$, general socialization $(b=.01, t=.23, p>.05)$, relationship building $(b=-.18, t$ 
$=-1.83, p>.05)$ and job satisfaction. At low levels of servant leadership, information seeking $(\mathrm{b}$ $=.46, t=4.61, p<.01)$ and general socializing $(\mathrm{b}=.23, t=3.57, p<.01)$ were significantly and positively related to job satisfaction. The nature of the relationship between feedback seeking ( $\beta$ $=.10, t=1.56, p>.05)$, relationship building $(\mathrm{b}=.20, t=1.89, p<.10)$ and job satisfaction, at low levels of servant leadership, was not statistically significant. This pattern of results supports the hypothesis that the relationship between newcomer proactive behaviors (specifically information seeking and general socializing behaviors) and job satisfaction was more positive when servant leadership was low.

Hypotheses 2a-2d predicted that newcomer proactive behaviors and servant leadership interact with respect to P-J fit. The interaction terms presented in Tables 2-5 were significant for information seeking, general socializing, and relationship building, but not for feedback seeking. Simple slope analyses showed that at high levels of servant leadership, there was no relationship between newcomer proactive behaviors and P-J fit $(b=.01, t=.13, p>.05$ for information seeking, $b=-.09, t=-.98, p>.05$ for general socializing and $b=-.07, t=-.56, p>.05$ for relationship building). However, at low levels of servant leadership, all three relationships were positive and significant $(b=.42, t=3.32, p<.01$ for information seeking, $b=.30, t=3.82, p<.01$ for general socializing, and $b=.30, t=2.26, p<.05$ for relationship building). The plots of these interactions are presented in Figures 3a, b, and c. These results provide support for Hypotheses 2a, 2c, and 2d, but fail to support Hypothesis $2 \mathrm{~b}$.

Finally, Hypotheses 3a-3d suggested that servant leadership would act as a moderator of newcomer proactive behaviors with respect to $\mathrm{P}-\mathrm{O}$ fit. The results presented in Tables 2-5 showed that the interaction terms of information seeking and relationship building with servant leadership were significant. The plots of these interactions are shown in Figures $4 \mathrm{a}$ and $4 \mathrm{~b}$. 
Simple slope analyses have shown that at high levels of servant leadership, newcomer information seeking $(b=.05, t=.40, p>.05)$ and relationship building $(b=-.08, t=-.62, p>$ .05) were not related to P-O fit. At low levels of servant leadership, newcomer information seeking $(b=.44, t=3.58, p<.01)$ and relationship building $(b=.25, t=1.88, p<.10)$ had more positive relations with P-O fit, providing partial support for Hypothesis $3 \mathrm{a}$ and $3 \mathrm{~d}$ but failing to support Hypotheses $3 b$ and 3c.

Finally, as a follow-up analysis we regressed each dependent variable on all main effects and interaction terms simultaneously. For job satisfaction as the outcome, the four interactions cumulatively explained $5.3 \%$ of the variance $(\Delta F=4.12, p<.01)$. The only significant interaction that emerged was between information seeking and servant leadership $(b=-.34, \mathrm{SE}=$ $.16, t=-2.18, p<.05)$. For P-J fit, the four interaction terms explained $5.5 \%$ of the variance $(\Delta F$ $=4.22, p<.01)$, with general socialization emerging as the only significant interaction $(b=-.35$, $\mathrm{SE}=.12, t=-2.79, p<.01)$. For P-O fit, the four interaction terms collectively explained $2.8 \%$ of the variance $(\Delta F=2.01, p<.10)$, and information seeking approached significance $(b=-.33$, $\mathrm{SE}=.19, t=-1.76, p<.10)$. In sum, servant leadership played a moderator role over newcomer proactive behaviors in general, with the most robust moderated relations emerging as the effects on information seeking and general socialization on outcomes.

\section{Discussion}

In this study, we investigated the moderating role of servant leadership for the relationship between a set of key newcomer proactive behaviors and subsequent newcomer fit and adjustment. Our results suggest, as proposed, that the positive effects of newcomer proactive behaviors on newcomer outcomes occur in the absence of servant leadership. Servant leadership was related to newcomers' early adjustment outcomes, in such a way that when servant 
leadership is high, newcomers experienced greater levels of job satisfaction and greater levels of person-job and person-organization fit. In contrast, newcomers' own proactive behaviors made a difference in the absence of servant leadership, suggesting that employees may be able to compensate for the type of help and support servant leaders provide through their own actions. Similarly, servant leadership was related to a reduction in the necessity of proactivity on the part of newcomers, by providing a rich environment in which adjustment takes place. The most consistent effects were found for newcomer information seeking and relationship building behaviors, suggesting the provision of servant leadership provides employees with the informational and relational resources that are useful for newcomer adjustment. In general, although employee perceptions of servant leadership were positively related to job satisfaction and perceived fit within the organization and with their jobs, employees who reported receiving lower levels of servant leadership behaviors were shown to be able to offset this lack of supporting servant leadership behaviors by engaging in proactive behaviors. Specifically, the more they engaged in feedback and information seeking, worked to build relationships, and socialized with coworkers, the higher their job satisfaction, P-O fit, and P-J fit.

The first contribution includes expanding our knowledge of the context surrounding new employee proactive behavior. Although differences in human resource practices and newcomer individual characteristics have provided critical knowledge in understanding the role of proactive newcomer behavior in enhancing socialization outcomes, a relatively ignored contextual variable in this literature is leadership. Results of the current investigation reveal that socialization outcomes are consistently positive under servant leaders, regardless of the degree to which newcomers engage in proactive behaviors. Only under conditions of low levels of servant leadership, did we find positive associations between proactive newcomer behaviors and 
outcomes. This finding suggests that both leadership style and newcomer behavior matter in different instances for socialization outcomes. That is, newcomers may experience job satisfaction and achieve fit with their jobs and organizations simply by being led by servant leaders. This possibility appears to identify a key boundary condition for proactive behaviors. Specifically, in the presence of servant leadership, newcomer proactive behaviors are not required in order for followers to fare well on key newcomer outcomes. Theoretically, this opens the door to further examination of how and when proactive behaviors matter for new employees. Moreover, this study provides empirical support for the aforementioned meta-analysis showing that servant leadership explains variance in key individual outcomes. Additional research is required to further support the meta-analysis in examining the efficacy of servant leadership compared with other leadership styles. This opportunity for future research is discussed in greater detail below.

Another contribution of the current investigation includes expanding the outcomes of proactive behavior. Our study has contributed to the proactive behavior literature to demonstrate that proactivity not only enhances job satisfaction, but also appears to be related to increased perceptions of both P-O and P-J fit. Although proactivity of undergraduate co-op students in short (4-month) assignments has been shown in a cross-sectional study to be related to P-O and P-J fit (Gruman et al., 2006), our results provide support for these relationships among full-time employees with proactive behaviors measured 3 months and fit measured 6 months after entry. By proactively accessing information, developing social connections, and building relationships, newcomers develop a clearer picture of their roles in the organization. Proactive behaviors also benefit newcomers by enabling them to tailor their jobs to meet their specific needs, thus serving to enhance their perception of fitting well with their jobs and organizations. Theoretically, not 
all aspects of newcomer adjustment, fit, and satisfaction are the same. By expanding the focus on additional outcomes, we are able to further extend our understanding of the nomological network of proactive behaviors.

\section{Practical Implications}

We sought to contribute to the proactive behavior literature by directly assessing how proactivity during a new employee's early time with an organization might relate to fit and adjustment. We did this in the hopes of expanding our understanding of the context in which contextual newcomer key proactive behaviors matter, and to what extent. In doing so, we questioned an underlying assumption that exists in the majority of work examining the relationship between newcomer proactive behavior and newcomer adjustment: the assumption that newcomer adjustment rests solely on the newcomer's own tendency toward proactivity, and is independent of the role of insiders. Thus, we examined an important boundary conditionwhether servant leadership was present- as a moderator of the proactive behavior to newcomer outcomes relationship. It is important to note that proactive behaviors were a key component of new employee success as indicated by fit and job satisfaction, and that for those employees with lower levels of proactivity, servant leadership served as an important substitute. This ties into the organizational socialization literature in important and practical ways. It appears that newcomers have at least two options at their disposal. On one hand, they may choose to engage in proactive behaviors, such as information seeking, to help them gain important information and support. These findings replicate and extend the paramount importance of new employee proactivity during the socialization process. On the other hand, they may find servant leaders to help them. Both were shown to provide viable ways to approach their adjustment. 
While organizational insiders, and leaders, in particular, have been identified as critical to the success or failure of newcomers, we have argued that servant leadership is especially wellsuited to addressing the needs of newcomers during the socialization process. Because servant leaders prioritize the needs of followers over their own needs (Greenleaf, 1970), they are wellpositioned to help their followers achieve success and feel good about their roles within organizations. Furthermore, given their focus on developing employees to their fullest potential (Liden et al., 2008), such leadership is especially salient for successful employee socialization. As noted in our introduction, we sought to focus on key newcomer outcomes that are personal in nature, including how newcomer proactive behavior relates to newcomer perceptions of job satisfaction as well as person-job and person-organization fit. By focusing on these well-being outcomes, we add to the expanding organizational socialization outcome literature.

This study also contributes to the mounting evidence in support of servant leadership. Not only does a servant leadership style create a positive work environment conducive to success, as previous studies have indicated, but it can actually lead to improved individual outcomes. The results clearly show the benefits of selecting and training leaders to maximize engagement in servant leadership behaviors, as followers of servant leaders were shown to be more satisfied with their jobs and perceived greater P-O and P-J fit than their counterparts whose leaders were perceived as exhibiting less servant leadership behavior. Although our results demonstrated that employees of leaders engaging less in servant leadership may overcome this liability by being proactive, employees vary considerably in their proclivity to engage in proactive behaviors, as clearly shown in the proactive personality literature (Crant, 2000). Because employees who are not prone to behave proactively, such as those low in proactive personality, may suffer lower job satisfaction and poorer fit with their jobs and organizations, organizations should either 
encourage employees to be more proactive or endeavor to build a servant leadership culture (Liden, Wayne et al., 2014).

\section{Potential Strengths, Limitations, and Future Research Directions}

Two methodological strengths of our investigation were a design that included gathering data at three points in time and the sampling of newcomers to the organization. Socialization field research has been dominated by samples of undergraduate students entering their first jobs. Although much has been learned from these studies, largely missing has been research involving newcomers of various ages and career stages, as characterizes the sample for the current investigation. Another strength was that collecting data from a single organization provides a built-in control for aspects of the context that may affect employee responses. Despite these strengths, the research design was limited by the collection of data from only one source. Although our research design with multiple data collection points serves to reduce the severity of this limitation, having only three months' separation between each time period allows for some possibility of same source common method variance, at least partially explaining the results. Even though all hypotheses involved interactions, which are less susceptible to same source bias, we suggest that future research designs include data collected from multiple sources and/or have longer intervals between time periods. An additional limitation is that despite studying a unique cultural context by collecting data in France, replication in other countries is needed to assess external validity. Replication is also needed in industries other than the financial sector studied in the current investigation.

And, although our data collection design included data across three time points, our study was not truly longitudinal because each study variable was measured at only one point in time. Because of this we do not know how newcomer proactive behavior patterns changed, or did not 
change, over time. We are also not able to make causal inferences given our research design. However, the ordering of our data collection was such that it did move beyond a simple common bound design. We encourage future research seeking to address questions around time (Ashforth, 2012) and the changing nature of proactivity over time during the organizational socialization process in a truly longitudinal design to allow for a replication and extension of our findings here. And, while we did purposely focus on new employees and their leaders, we did not gather data from all coworkers. Such insights would be helpful and we encourage this approach in future research.

Although not a focus of the current investigation, the positive relationships found between servant leadership and proactive behaviors are intriguing and suggest hypotheses for future studies. For example, servant leadership might be modeled as an antecedent of proactive behavior in addition to its role as a moderator of relationships between proactive behavior and outcomes. Studies might also be conducted to explore the mechanisms through which servant leadership enhances follower proactive behavior. For example, through empowering behaviors and a focus on bringing out the full potential in all followers, servant leaders help to build the confidence to be proactive at work. Servant leaders, who strive to be ethical and open to dissenting perspectives offered by followers, are also likely to create environments that provide the psychological safety that reduces the risk associated with being proactive. Finally, future studies may consider the mechanisms by which servant leadership serves as a moderator of the relation between newcomer proactive behaviors and socialization outcomes. For example, servant leaders may enhance state self-efficacy (Walumbwa, Hartnell, \& Oke, 2010), which could be the reason for the observed moderating role of servant leadership on newcomer proactive behaviors. 
We conducted this study in France, a country that is under-represented in the organizational literature, which we saw as a contribution adding to the burgeoning proactive behavior and newcomer organizational socialization literature. But, because we focused on a single company within a specific industry, it is not clear how representative this sample is for understanding non-knowledge related work or workers. We encourage further work in a variety of contexts to assess the robustness of our findings. Work that tests and seeks to replicate and extend this study in other cultural contexts is encouraged.

While a great deal of work has examined the antecedents and outcomes associated with proactive personality (Bateman \& Crant, 1993; Crant \& Bateman, 2000; Seibert, Kraimer, \& Crant, 2001), specifically in the newcomer socialization setting (Kammeyer-Mueller \& Wanberg, 2003), we instead focus on actual behaviors. This is because behaviors are more malleable to change than one's personality. Thus, we felt that our findings would be more amenable to helping new employees understand the pros and cons of proactive behaviors in the socialization context by focusing on them. However, it would be fruitful for future research to examine both proactive personality and proactive behaviors to see how they interact with servant leadership.

\section{Conclusion}

In conclusion, our study is the first to examine new employee proactive behaviors and servant leadership at the same time. As such, it has illustrated that proactive behaviors matter when servant leadership is low. However, having both proactive newcomer behavior and servant leadership in place is the ideal scenario for helping new employees to fit into their new jobs while feeling satisfied. This highlights specific ways in which newcomers, managers, and organizations can help to engage in specific behaviors and to facilitate positive contexts for successful socialization. 


\section{References}

Allen, T., Eby, L., Chao, G., \& Bauer, T. N. (2017). Taking stock of two relational aspects of organizational life: Tracing the history and shaping the future of socialization and mentoring research. Journal of Applied Psychology, 102, 324-337.

Ashford, S. J., \& Black, J. S. (1996). Proactivity during organizational entry: The role of desire for control. Journal of Applied Psychology, 81, 199-214.

Ashforth, B. E. (2012). The role of time in socialization dynamics. In C. R. Wanberg (Ed.), The Oxford handbook of organizational socialization. New York, NY: Oxford University Press.

Bateman, T. S., \& Crant, J. M. (1993). The proactive component of organizational behavior: A measure and correlates. Journal of Organizational Behavior, 14, 103-118.

Bauer, T. N., \& Green, S. G. (1994). Effect of newcomer involvement in work-related activities: A longitudinal study of socialization. Journal of Applied Psychology, 79, 211-223.

Bauer, T. N., Bodner, T., Erdogan, B., Truxillo, D. M., \& Tucker, J. S. (2007). Newcomer adjustment during organizational socialization: A meta-analytic review of antecedents, outcomes, and methods. Journal of Applied Psychology, 92, 707-721.

Brislin, R. W. (1970). Back-translation for cross-cultural research. Journal of Cross-Cultural Psychology, 1, 185-216.

Bureau of Labor Statistics. (2015). Number of jobs held, labor market activity, and earnings growth among the youngest baby boomers: Results from a longitudinal survey. Washington, D.C., U.S.A. Retrieved on September 13, 2018 from http://www.bls.gov/news.release/pdf/nlsoy.pdf. 
Cable, D. M., Gino, F., \& Staats, B. R. (2013). Breaking them in or eliciting their best? Reframing socialization around newcomers' authentic self-expression. Administrative Science Quarterly, $58,1-36$.

Chiniara, M., \& Bentein, K. (2018). The servant leadership advantage: When perceiving low differentiation in leader-member relationship quality influences team cohesion, team task performance and service OCB. Leadership Quarterly, 29, 333-345.

Crant, J. M. (2000). Proactive behavior in organizations. Journal of Management, 26, 435-462.

Crant, J. M., \& Bateman, T. S. (2000). Charismatic leadership viewed from above: The impact of proactive personality. Journal of Organizational Behavior, 21, 63-75.

Eisenberger, R., Stinglhamber, F., Vandenberghe, C., Sucharski, I. L., \& Rhoades, L. (2002).

Perceived supervisor support: Contributions to perceived organizational support and employee retention. Journal of Applied Psychology, 87, 565-573.

Ellis, A. M., Bauer, T. N., Mansfield, L. R., Erdogan, B., Truxillo, D. M., \& Simon, L. S. (2015). Navigating uncharted waters: Newcomer socialization through the lens of stress theory. Journal of Management, 41, 203-235.

Greenleaf, R. K. (1970). The servant as leader. Cambridge, MA: Center for Applied Studies.

Gruman, J. A., Saks, A. M., \& Zweig, D. I. (2006). Organizational socialization tactics and newcomer proactive behaviors: An integrative study. Journal of Vocational Behavior, 69, 90104.

Hackman, J. R., \& Oldham, G. R. (1975). Development of the Job Diagnostic Survey. Journal of Applied Psychology, 60, 159-170. 
Hoch, J. E., Bommer, W. H., Dulebohn, W. H., \& Wu, D. (2018). Do ethical, authentic, and servant leadership explain variance above and beyond transformational leadership? A metaanalysis. Journal of Management, 44, 501-529.

Hu, J., \& Liden, R.C. (2011). Antecedents of team potency and team effectiveness: An examination of goal and process clarity and servant leadership. Journal of Applied Psychology, 96, 851-862.

Institut National de la Statistique et des Etudes Economiques. (2014). Emploi et Salaires.

Jones, G. R. (1983). Psychological orientation and the process of organizational socialization: An interactionist perspective. Academy of Management Review, 8, 464-474.

Kammeyer-Mueller, J. D., \& Wanberg, C. (2003). Unwrapping the organizational entry process: Disentangling multiple antecedents and their pathways to adjustment. Journal of Applied Psychology, 88, 779-794.

Kim, T.-Y., Cable, D. M., \& Kim, S.-P. (2005). Socialization tactics, employee proactivity, and person-organization fit. Journal of Applied Psychology, 90, 232-241.

Kristof, A. L. (1996). Person-organization fit: An integrative review of its conceptualizations, measurement, and implications. Personnel Psychology, 49, 1-49.

Kristof-Brown, A. L., Zimmerman, R. D., \& Johnson, E. C. (2005). Consequences of individuals' fit at work: A meta-analysis of person-job, person-organization, person-group, and personsupervisor fit. Personnel Psychology, 58, 281-342.

Liden, R. C., Bauer, T. N., \& Erdogan, B. (2004). The role of leader-member exchange in the forming and dynamic relationship between employee and employer. In J. Coyle-Shapiro, L. Shore, S. Taylor, \& L. Tetrick (Eds.), The employment relationship: Examining psychological and contextual perspectives (pp. 226-250). Oxford, UK: Oxford University Press. 
Liden, R. C., Panaccio, A., Meuser, J. D., Hu, J., \& Wayne, S. J. (2014). Servant leadership: Antecedents, processes, and outcomes. In Day, D.V. (Ed.) The Oxford handbook of leadership and organizations (pp. 357-379). Oxford, England: Oxford University Press.

Liden, R., Wayne, S., Liao, C., \& Meuser, J. (2014). Servant leadership and serving culture: Influence on individual and unit performance. Academy of Management Journal, 57, 14341452.

Locke, E. A. (1976). The nature and causes of job satisfaction. In M. D. Dunnette (Ed.), Handbook of industrial and organizational psychology (pp. 1297-1349). Chicago: Rand McNally.

Morrison, E. W. (1993). Longitudinal study of the effects of information seeking on newcomer socialization. Journal of Applied Psychology, 78, 173-183.

Panaccio, A., Donia, M., Saint-Michel, S., \& Liden, R. (2015). Servant leadership and well-being. In R. Burke, C. Cooper, \& K. Page (Eds.), Flourishing in life, work, and careers: New horizons in management (pp. 334-358). Cheltenham, UK: Edward Elgar Publishing.

Perrot, S., Bauer, T. N., Abonneau, D., Campoy, E., Erdogan, B., \& Liden, R. C. (2014). Organizational socialization tactics and newcomer adjustment: The moderating role of perceived organizational support. Group \& Organization Management, 39, 247-273.

Reichers, A. E. (1987). An interactionist perspective on newcomer socialization rates. Academy of Management Review, 12, 278-287.

Saks, A. M., \& Ashforth, B. E. (1997). A longitudinal investigation of the relationships between job information sources, applicant perceptions of fit, and work outcomes. Personnel Psychology, 50, 395-426.

Saks, A. M., Gruman, J. A., \& Cooper-Thomas, H. (2011). The neglected role of proactive behavior and outcomes in newcomer socialization. Journal of Vocational Behavior, 79, 36-46. 
Saks, A. M., Uggerslev, K. L., \& Fassina, N. E. (2007). Socialization tactics and newcomer adjustment: A meta-analytic review and test of a model. Journal of Vocational Behavior, 70, 413-446.

Schaubroeck, J., Lam, S. S., \& Peng, A. C. (2011). Cognition-based and affect-based trust as mediators of leader behavior influences on team performance. Journal of Applied Psychology, $96,863-871$.

Seibert, S. E., Kraimer, M. L., \& Crant, J. M. (2001). What do proactive people do? A longitudinal model linking proactive personality and career success. Personnel Psychology, 54, 845-874.

Tornau, K., \& Frese, M. (2013). Construct clean-up in proactivity research: A meta-analysis on the nomological net of work-related proactivity concepts and their incremental validities. Applied Psychology: An International Review, 62, 44-96.

Van Dierendonck, D. (2011). Servant leadership: A review and synthesis. Journal of Management, $37,1228-1261$.

Van Maanen, J., \& Schein, E. H. (1979). Toward a theory of organizational socialization. In B. Staw (Ed.), Research in organizational behavior (pp. 209-264). Greenwich, CT: JAI.

Walumbwa, F. O., Hartnell, C. A., \& Oke, A. (2010). Servant leadership, procedural justice climate, service climate, employee attitudes, and organizational citizenship behavior: A crosslevel investigation. Journal of Applied Psychology, 95, 517-529.

Wanberg, C. R. (2012). The Oxford handbook of organizational socialization. New York: Oxford Press.

Yu, K. Y., \& Davis, H. M. (2016). Autonomy's impact on newcomer proactive behaviour and socialization: A needs-supplies fit perspective. Journal of Occupational and Organizational Psychology, 89, 172-197. 
Table 1 .

Descriptive Statistics and Correlations Among Study Variables.

\begin{tabular}{|c|c|c|c|c|c|c|c|c|c|}
\hline Variable & Mean & SD & 1 & 2 & 3 & 4 & 5 & 6 & 7 \\
\hline 1. Servant Leadership (T2) & 3.59 & .47 & & & & & $\nabla$ & & \\
\hline 2. Information Seeking (T2) & 4.25 & .50 & $.25^{* *}$ & & & & & & \\
\hline 3. Feedback Seeking (T2) & 3.79 & .78 & $.29 * *$ & $.14^{*}$ & & & & & \\
\hline 4. General Socializing (T2) & 3.18 & .82 & $.39 * *$ & $.21 * *$ & $.19 * *$ & & & & \\
\hline 5. Relationship Building (T2) & 3.87 & .56 & $.45^{* * *}$ & $.36^{* *}$ & $.30 * *$ & $.30^{* *}$ & & & \\
\hline 6. Job Satisfaction (T3) & 4.21 & & $.33 * *$ & $.29 * *$ & $.15^{*}$ & $.30^{* *}$ & $.22 * *$ & & \\
\hline 7. P-J Fit (T3) & & & $.34 * *$ & $.25^{* *}$ & .12 & $.27 * *$ & $.26^{* *}$ & $.76^{* *}$ & \\
\hline 8. P-O Fit (T3) & 4.00 & .79 & $.31^{* *}$ & $.26^{* *}$ & .11 & $.23^{* *}$ & $.23^{* *}$ & $.69^{* *}$ & $.64 * *$ \\
\hline
\end{tabular}

Note. $N=247 . \mathrm{T} 2$ and T3 denote the timing of when the data were collected with T2 being 3 -months post-entry, and T3 being 6 months post-entry. P-J Fit refers to person-job fit. P-O Fit refers to person-organization fit.

$* p<.05 ; * * p<.01$ 
Table 2.

Results of Moderation Analysis with Servant Leadership Moderating the Effects of Information Seeking

\begin{tabular}{|c|c|c|c|c|c|c|c|c|c|c|c|c|c|c|c|}
\hline & \multicolumn{5}{|c|}{ Job Satisfaction (T3) } & \multicolumn{5}{|c|}{ P-J Fit (T3) } & \multicolumn{5}{|c|}{ P-O Fit (T3) } \\
\hline & $\mathrm{b}$ & $\mathrm{SE}$ & $\mathrm{t}$ & LLCI & ULCI & $\mathrm{b}$ & SE & $\mathrm{t}$ & LLCI & ULCI & $\mathrm{b}$ & SE & $\mathrm{t}$ & LLCI & ULCI \\
\hline Servant leadership & 2.17 & .56 & $3.85 * *$ & 1.06 & 3.29 & 2.19 & .71 & $3.09 * *$ & .79 & 3.59 & 2.10 & .70 & $3.02 * *$ & .73 & 3.47 \\
\hline Information seeking & 1.85 & .48 & $3.89 * *$ & .91 & 2.79 & 1.76 & .60 & $2.93 * *$ & .58 & 2.94 & 1.73 & .59 & $2.95 * *$ & .58 & 2.89 \\
\hline Feedback seeking & .04 & .05 & .70 & -.07 & .14 & .01 & .07 & .08 & -.12 & .13 & .00 & .06 & .05 & -.12 & .13 \\
\hline General socialization & .15 & .05 & $2.87 * *$ & .05 & .25 & .14 & .06 & $2.23 *$ & .02 & .27 & .10 & .06 & 1.55 & -.03 & .22 \\
\hline Relationship building & .02 & .08 & .22 & -.14 & .17 & .12 & .10 & 1.22 & -.08 & .33 & .09 & .10 & .94 & -.10 & .29 \\
\hline Servant leadership $\mathrm{x}$ & -.45 & .13 & $-3.38 * *$ & -.71 & -.19 & & .17 & $-2.59 *$ & -.76 & -.10 & -.41 & .16 & $-2.55^{*}$ & -.74 & -.09 \\
\hline \multicolumn{16}{|l|}{ information seeking } \\
\hline \multicolumn{16}{|c|}{ Conditional effect of servant leadership } \\
\hline$-1 \mathrm{SD}$ & .46 & .10 & $4.61 * *$ & .26 & .66 & .42 & .13 & $3.32 * *$ & .17 & .67 & .44 & .12 & $3.58 * *$ & .20 & .69 \\
\hline Mean & .25 & .08 & $3.07 * *$ & .09 & .41 & .22 & .10 & $2.09 *$ & .01 & .42 & .25 & .10 & $2.44^{*}$ & .05 & .45 \\
\hline $1 \mathrm{SD}$ & .04 & .11 & .39 & -.17 & .25 & .01 & .13 & .10 & -.25 & .28 & .05 & .13 & .40 & -.21 & .31 \\
\hline$R^{2}$ & \multicolumn{5}{|c|}{.22} & \multicolumn{5}{|c|}{.19} & \multicolumn{5}{|c|}{.16} \\
\hline$F(\mathrm{df} 1, \mathrm{df} 2)$ & \multicolumn{5}{|c|}{$11.28 * *(6,240)$} & \multicolumn{5}{|c|}{$9.09 * *(6,240)$} & \multicolumn{5}{|c|}{$7.83 * *(6,240)$} \\
\hline$\Delta R^{2}$ & \multicolumn{5}{|c|}{.04} & \multicolumn{5}{|c|}{.02} & \multicolumn{5}{|c|}{.02} \\
\hline$\Delta F(\mathrm{df} 1, \mathrm{df} 2)$ & \multicolumn{5}{|c|}{$11.41 * *(1,240)$} & \multicolumn{5}{|c|}{$6.70 * *(1,240)$} & \multicolumn{5}{|c|}{$6.48 *(1,240)$} \\
\hline
\end{tabular}

Note. $N=247$. All predictor variables were gathered at Time 2 (3-months post-entry). T3 indicates 6-months post-entry. P-J Fit refers to person-job fit. P-O Fit refers to person-organization fit. $\Delta R^{2}$ and $\Delta F$ denote changes in $R$ and $\mathrm{F}$ when the interaction term is added to the equation. 
Table 3.

Results of Moderation Analysis with Servant Leadership Moderating the Effects of Feedback Seeking

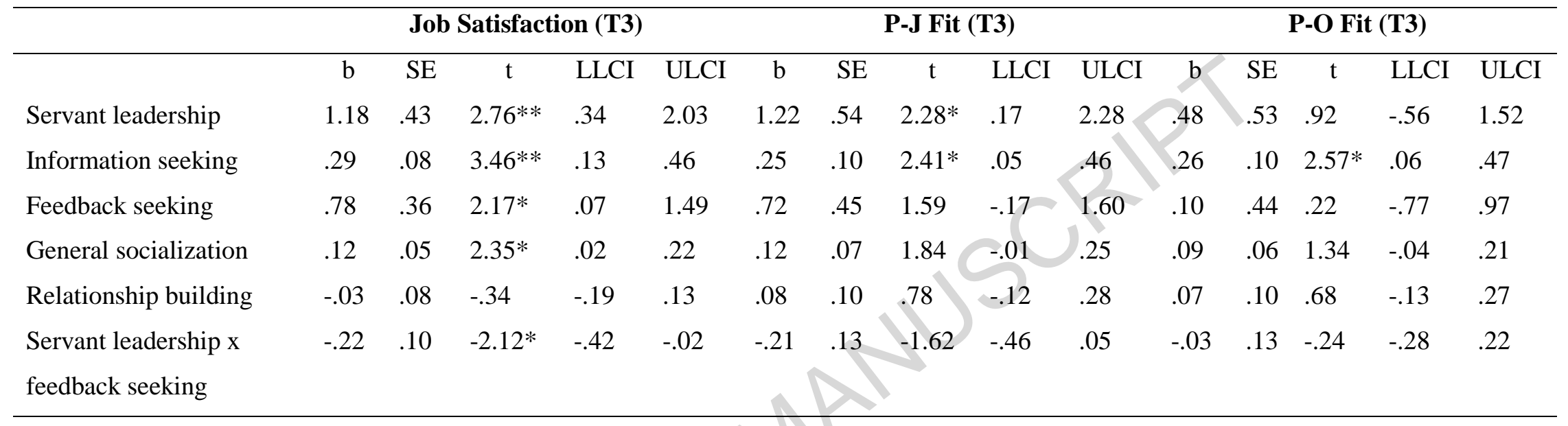

Conditional effect of servant leadership

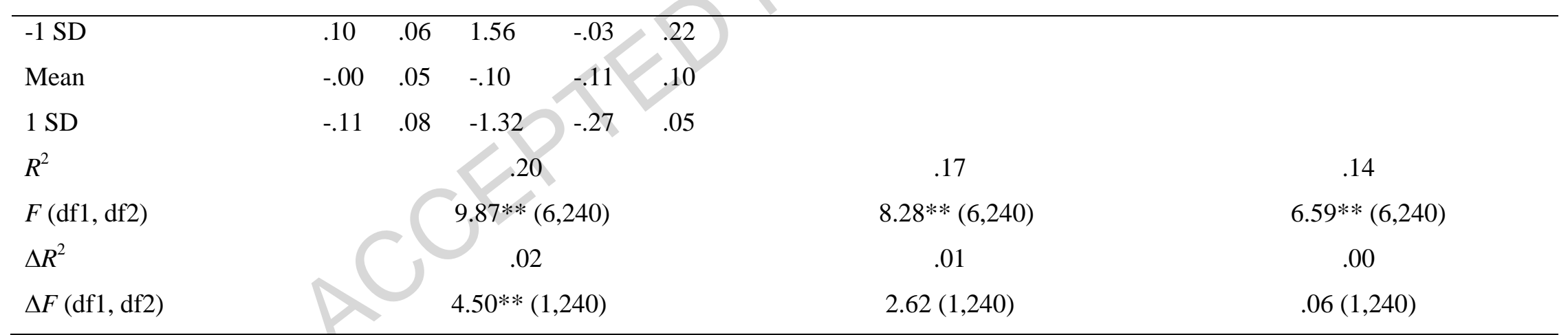

Note. $N=247$. All predictor variables were gathered at Time 2 (3-months post-entry). T3 indicates 6-months post-entry. P-J Fit refers to person-job fit. P-O Fit refers to person-organization fit. $\Delta R^{2}$ and $\Delta F$ denote changes in $R$ and $\mathrm{F}$ when the interaction term is added to the equation.

$* p<.05 ; * * p<.01$. 
Table 4.

Results of Moderation Analysis with Servant Leadership Moderating the Effects of General Socialization

\begin{tabular}{|c|c|c|c|c|c|c|c|c|c|c|c|c|c|c|c|}
\hline & \multicolumn{5}{|c|}{ Job Satisfaction (T3) } & \multicolumn{5}{|c|}{ P-J Fit (T3) } & \multicolumn{5}{|c|}{ P-O Fit (T3) } \\
\hline & $\mathrm{b}$ & SE & $\mathrm{t}$ & LLCI & ULCI & $\mathrm{b}$ & SE & $\mathrm{t}$ & LLCI & ULCI & $\mathrm{b}$ & $\mathrm{SE}$ & $\mathrm{t}$ & LLCI & ULCI \\
\hline Servant leadership & 1.02 & .31 & $3.28 * *$ & .41 & 1.63 & 1.70 & .38 & $4.45^{* *}$ & .95 & 2.45 & .38 & .38 & .98 & -.38 & 1.13 \\
\hline Information seeking & .28 & .08 & $3.41 * *$ & .12 & .45 & .26 & .10 & $2.54^{*}$ & .06 & & .26 & .10 & $2.55^{*}$ & .06 & .46 \\
\hline Feedback seeking & .01 & .05 & .26 & -.09 & .12 & -.03 & .06 & -.42 & -.15 & .10 & -.01 & .06 & -.11 & -.14 & .12 \\
\hline General socialization & .92 & .32 & $2.84 * *$ & .28 & 1.56 & 1.56 & .40 & $3.92 * *$ & .78 & 2.34 & .11 & .40 & .27 & -.68 & .89 \\
\hline Relationship building & .00 & .08 & .02 & -.16 & .16 & .12 & .10 & 1.15 & -.08 & .31 & .07 & .10 & .71 & -.13 & .27 \\
\hline Servant leadership $\mathrm{x}$ & -.22 & .09 & $-2.45^{*}$ & -.40 & -.04 & -.41 & & $-3.64 * *$ & -.63 & -.19 & -.01 & .11 & -.05 & -.23 & .22 \\
\hline general socialization & & & & & & & & & & & & & & & \\
\hline Conditional effect of s & eade & & & & & & & & & & & & & & \\
\hline$-1 \mathrm{SD}$ & .23 & .06 & $3.57 * *$ & .10 & 35 & .30 & .08 & $3.82 * *$ & .14 & .45 & & & & & \\
\hline Mean & .12 & .05 & $2.33^{*}$ & & 22 & .11 & .06 & 1.66 & -.02 & .23 & & & & & \\
\hline $1 \mathrm{SD}$ & .01 & .07 & & -.12 & .16 & -.09 & .09 & -.98 & -.26 & .09 & & & & & \\
\hline$R^{2}$ & & & & & & & & .21 & & & & & .14 & & \\
\hline$F(\mathrm{df} 1, \mathrm{df} 2)$ & & & $17 * *$ & 240) & & & & $10.39 * *($ & 240) & & & & $.58 * *(6$ & 240) & \\
\hline$\Delta R^{2}$ & & & .02 & & & & & .04 & & & & & .00 & & \\
\hline$\Delta F(\mathrm{df} 1, \mathrm{df} 2)$ & & & $6.00 *(1$, & 40) & & & & $13.23 * *($ & 240) & & & & $.00(1$, & 40) & \\
\hline
\end{tabular}

Note. $N=247$. All predictor variables were gathered at Time 2 (3-months post-entry). T3 indicates 6-months post-entry. P-J Fit refers to person-job fit. P-O Fit refers to person-organization fit. $\Delta R^{2}$ and $\Delta F$ denote changes in $R$ and $\mathrm{F}$ when the interaction term is added to the equation. $* p<.05 ; * * p<.01$. 
Table 5.

Results of Moderation Analysis with Servant Leadership Moderating the Effects of Relationship Building

\begin{tabular}{|c|c|c|c|c|c|c|c|c|c|c|c|c|c|c|c|}
\hline & \multicolumn{5}{|c|}{ Job Satisfaction (T3) } & \multicolumn{5}{|c|}{ P-J Fit (T3) } & \multicolumn{5}{|c|}{ P-O Fit (T3) } \\
\hline & $\mathrm{b}$ & $\mathrm{SE}$ & $\mathrm{t}$ & LLCI & ULCI & $\mathrm{b}$ & SE & $\mathrm{t}$ & LLCI & ULCI & $\mathrm{b}$ & SE & $\mathrm{t}$ & LLCI & ULCI \\
\hline Servant leadership & 1.90 & .55 & $3.49 * *$ & .83 & 2.98 & 1.94 & .69 & $2.82 * *$ & .59 & 3.29 & 1.71 & .67 & $2.54^{*}$ & .38 & 3.03 \\
\hline Information seeking & .28 & .08 & $3.44 * *$ & .12 & .45 & .25 & .10 & $2.38 *$ & .04 & & .28 & .10 & $2.71 * *$ & .08 & .48 \\
\hline Feedback seeking & .01 & .05 & .10 & -.10 & .11 & -.02 & .07 & -.38 & -.15 & .10 & -.02 & .06 & -.37 & -.15 & .10 \\
\hline General socialization & .14 & .05 & $2.64 * *$ & .03 & .24 & .13 & .06 & $2.05 *$ & 01 & .26 & .09 & .06 & 1.38 & -.04 & .21 \\
\hline Relationship building & 1.48 & .50 & $2.94 * *$ & .49 & 2.47 & 1.54 & .63 & $2.44^{*}$ & .29 & 2.78 & 1.32 & .62 & $2.13^{*}$ & .10 & 2.54 \\
\hline Servant leadership $\mathrm{x}$ & -.41 & .14 & $-2.99 * *$ & -.68 & -.14 & -.40 & .17 & $-2.30 *$ & -.74 & -.06 & -.34 & .17 & $-2.04 *$ & -.68 & -.01 \\
\hline
\end{tabular}

Conditional effect of servant leadership

\begin{tabular}{|c|c|c|c|c|c|c|c|c|c|c|c|c|c|c|}
\hline$-1 \mathrm{SD}$ & .20 & .11 & 1.89 & -.01 & .30 & .13 & $2.26^{*}$ & .04 & .57 & .25 & .13 & 1.88 & -.01 & .51 \\
\hline Mean & .01 & .08 & .12 & & .12 & .10 & 1.14 & -.08 & .32 & .08 & .10 & .85 & -.11 & .28 \\
\hline $1 \mathrm{SD}$ & -.18 & .10 & -1.83 & & -.07 & .13 & -.56 & -.32 & .17 & -.08 & .12 & -.62 & -.32 & .17 \\
\hline$R^{2}$ & & & & & \multicolumn{5}{|c|}{.18} & \multicolumn{5}{|c|}{.16} \\
\hline$F(\mathrm{df} 1, \mathrm{df} 2)$ & & & $10.77 *$ & 240) & \multicolumn{5}{|c|}{$8.82 * *(6,240)$} & \multicolumn{5}{|c|}{$7.39 * *(6,240)$} \\
\hline$\Delta R^{2}$ & & & & & \multicolumn{5}{|c|}{.02} & \multicolumn{5}{|c|}{.01} \\
\hline$\Delta F(\mathrm{df} 1, \mathrm{df} 2)$ & & & $8.94 * *$ & 40) & \multicolumn{5}{|c|}{$5.32 *(1,240)$} & \multicolumn{5}{|c|}{$4.17^{*}(1,240)$} \\
\hline
\end{tabular}

Note. $N=247$. All predictor variables were gather at Time 2 (3-months post-entry). T3 indicates 6-months post-entry. P-J Fit refers to person-job fit. P-O Fit refers to person-organization fit. $\Delta R^{2}$ and $\Delta F$ denote changes in $R$ and $\mathrm{F}$ when the interaction term is added to the equation. 
$\underline{\text { Newcomer Proactive Behaviors }}$

Information Seeking (T2)

Feedback Seeking (T2)

General Socializing (T2)

Relationship Building (T2)

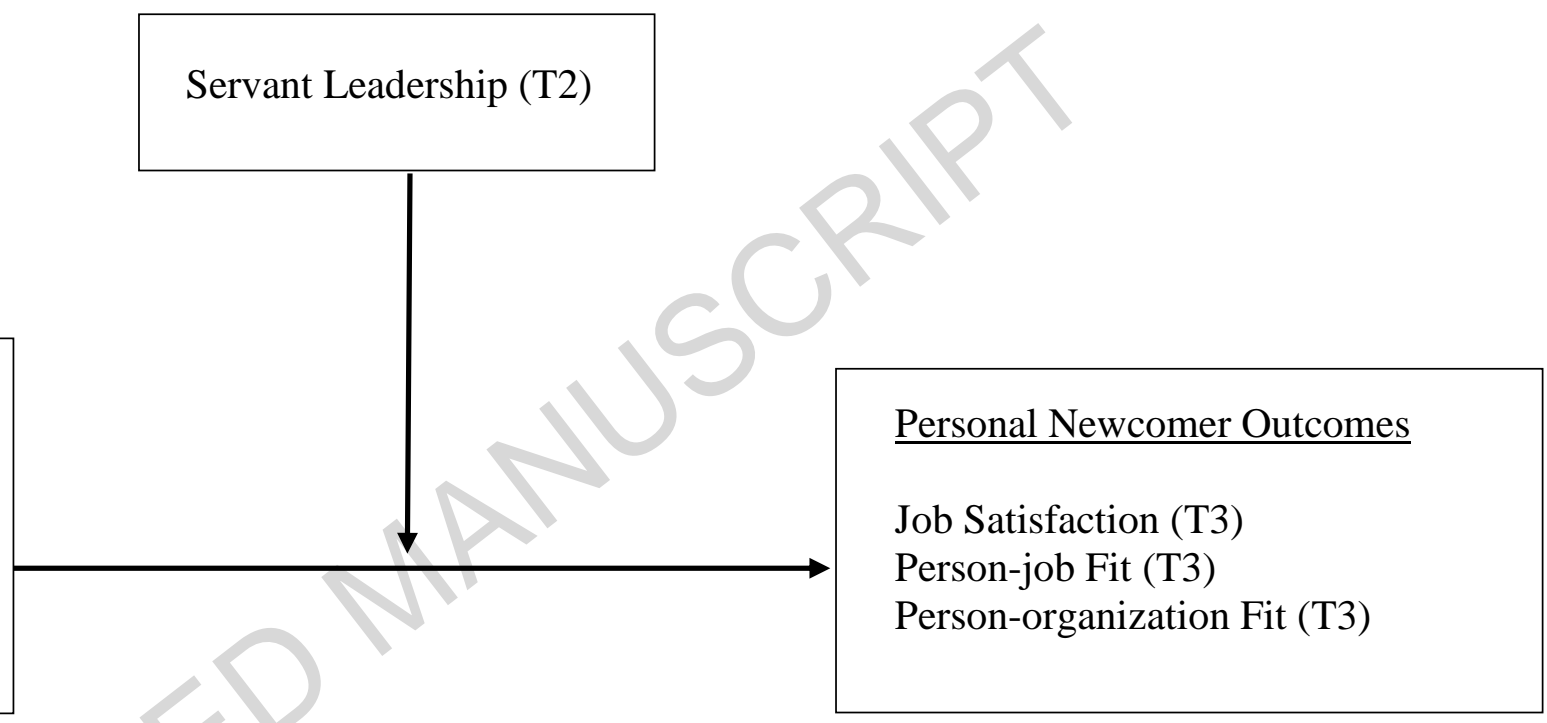

Figure 1. Proposed conceptual model. 


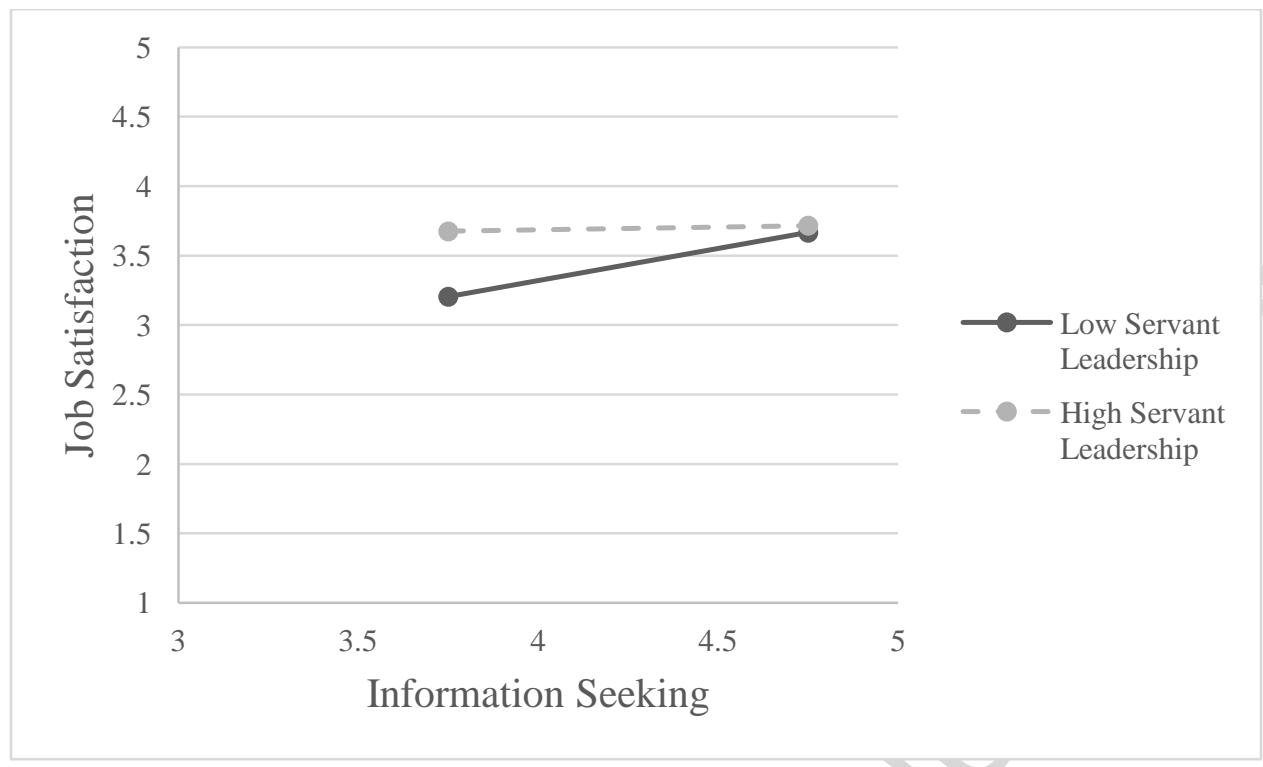

Figure 2a. The interaction of information seeking and servant leadership with respect to job satisfaction.

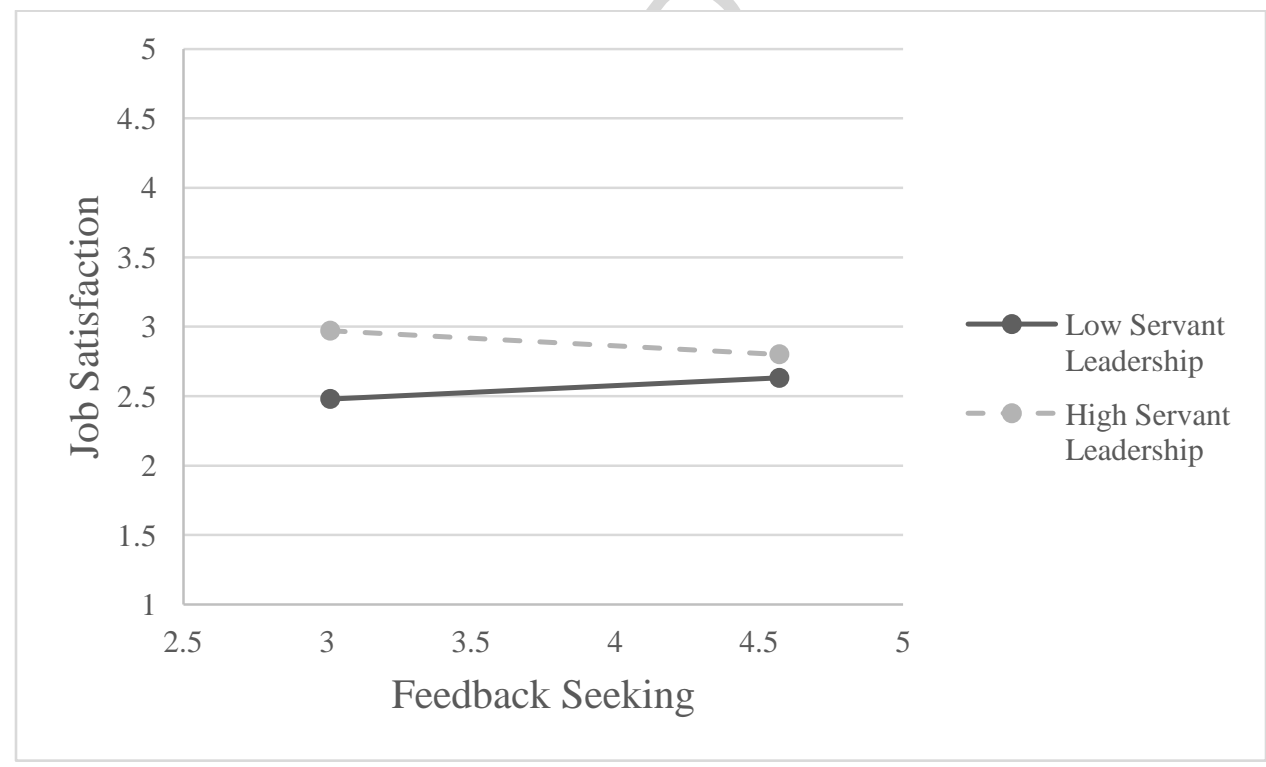

Figure $2 b$. The interaction of feedback seeking and servant leadership with respect to job satisfaction. 


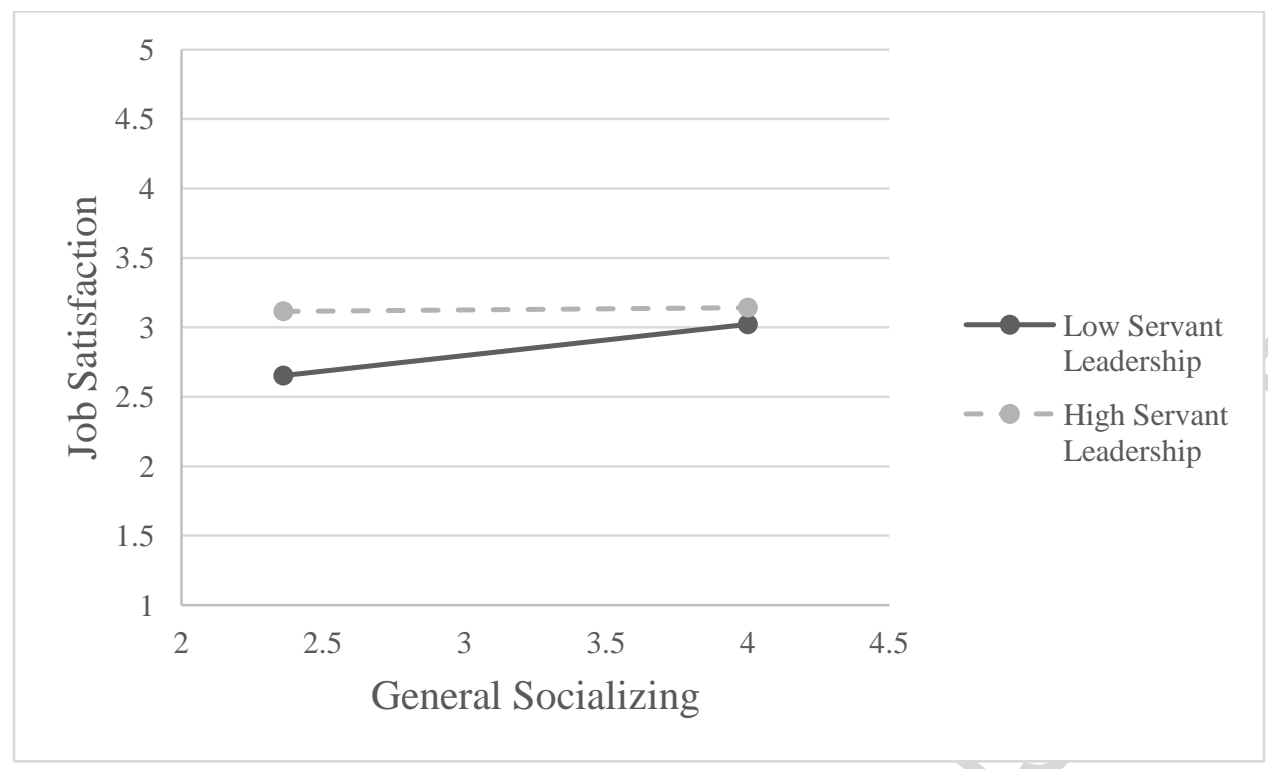

Figure 2c. The interaction of general socializing and servant leadership with respect to job satisfaction.

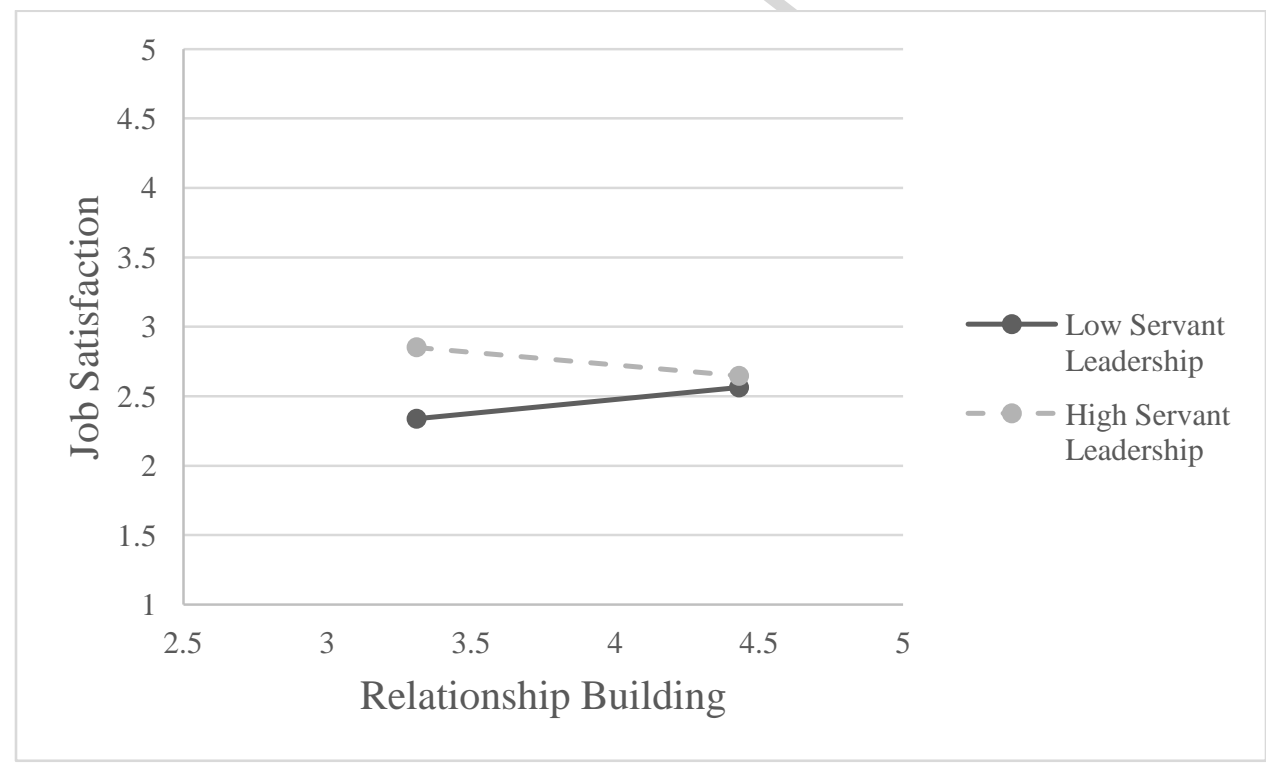

Figure $2 d$. The interaction of relationship building and servant leadership with respect to job satisfaction. 


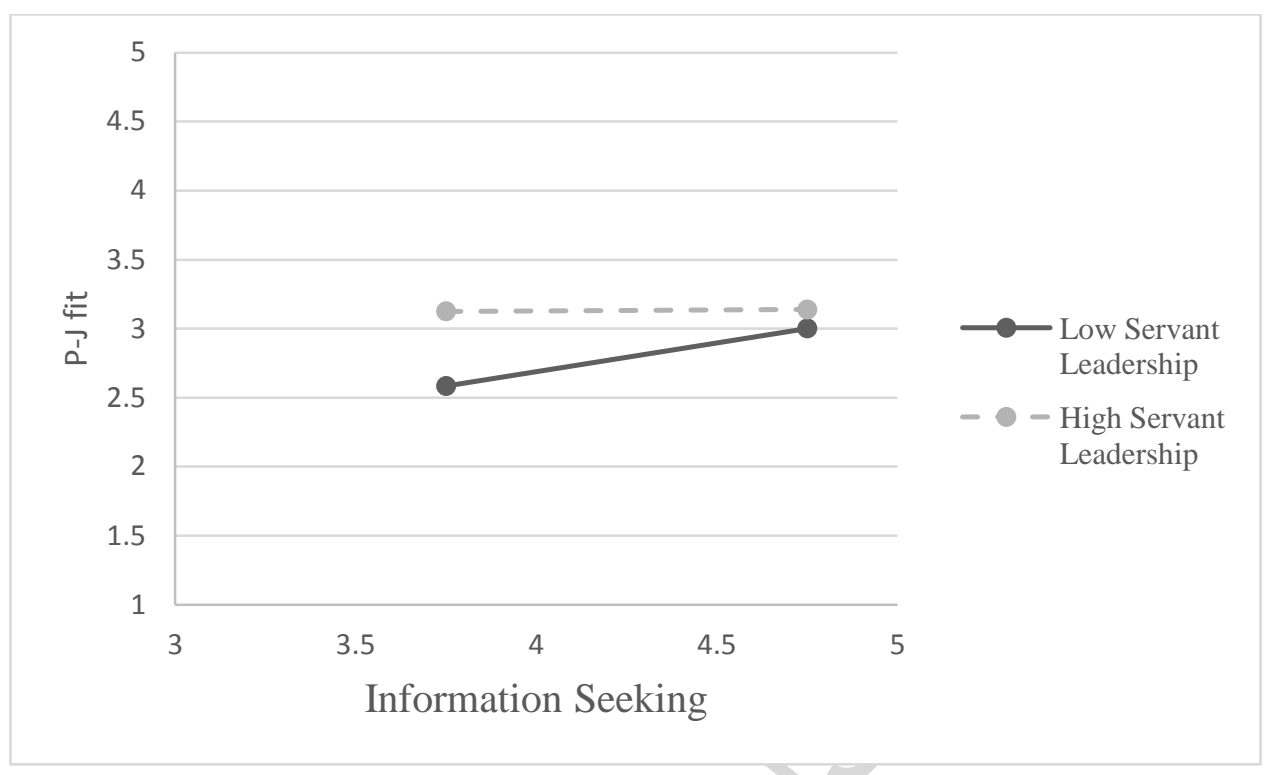

Figure $3 a$. The interaction of information seeking and servant leadership with respect to P-J fit.

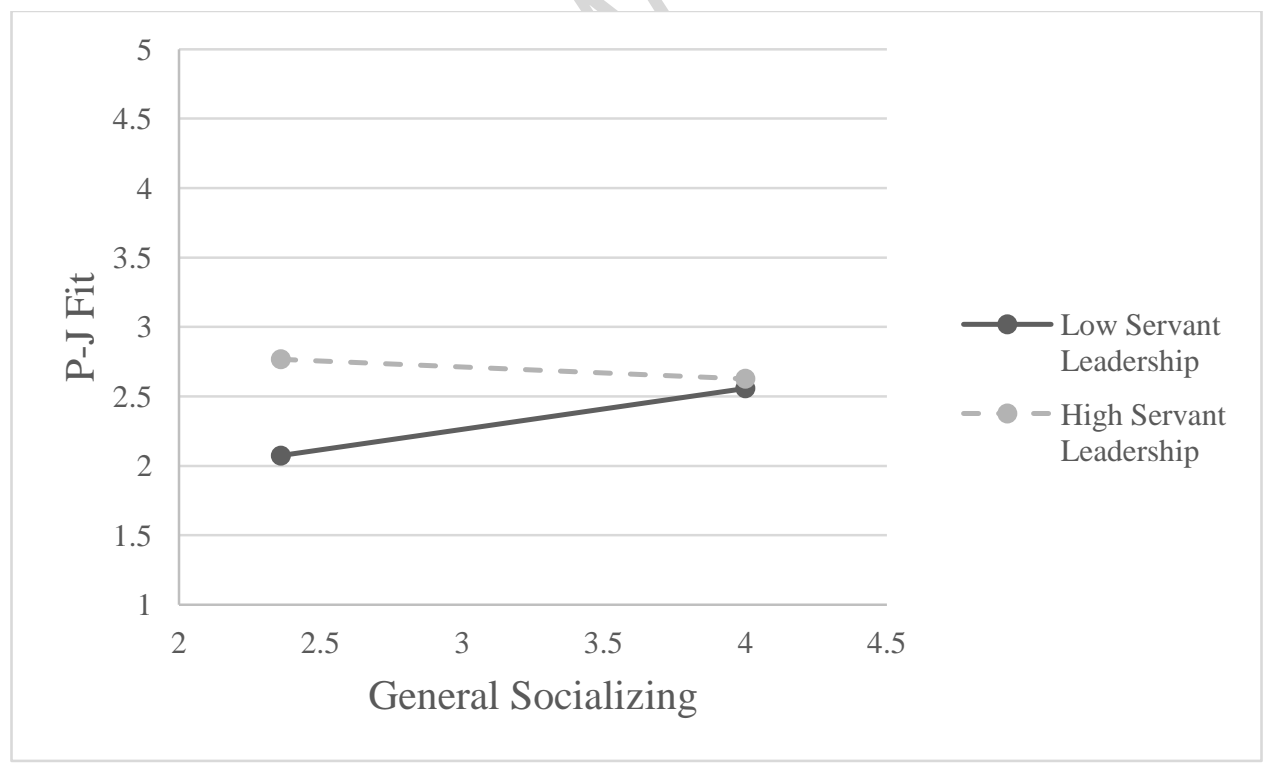

Figure $3 b$. The interaction of general socializing and servant leadership with respect to P-J fit. 


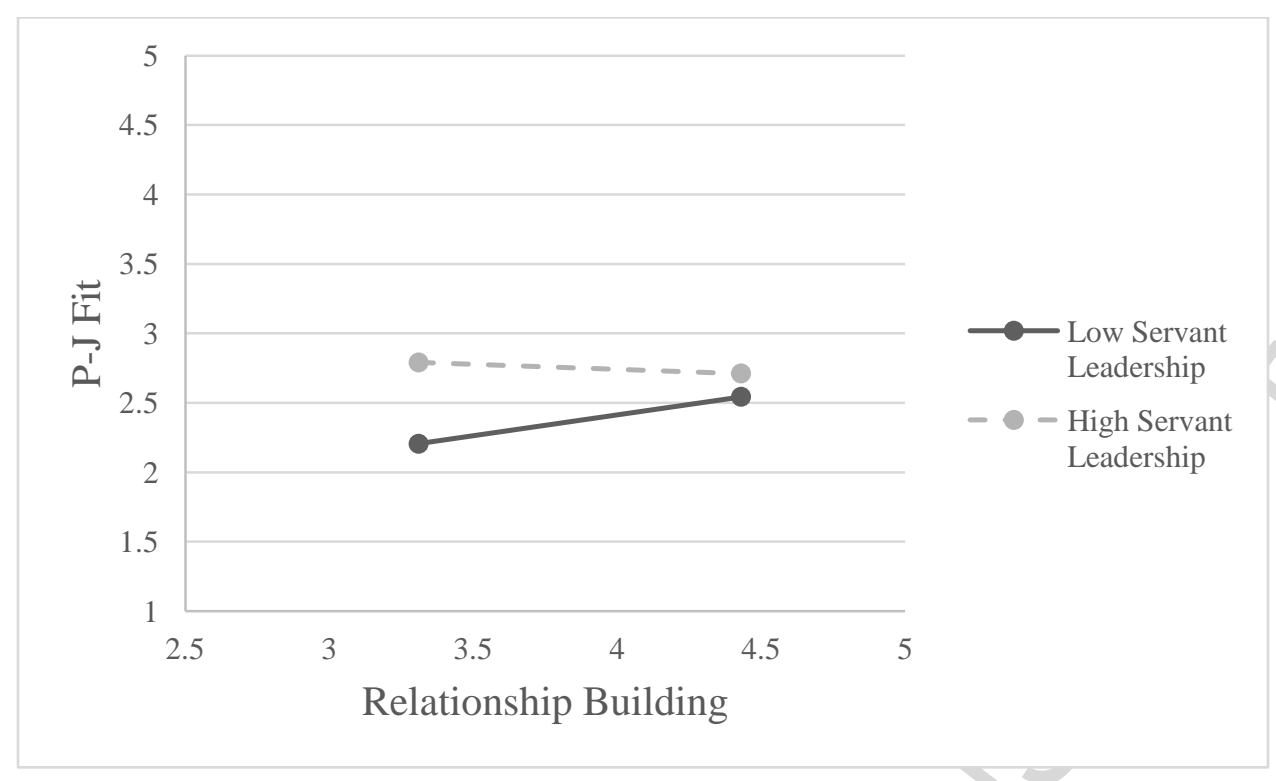

Figure 3c. The interaction of relationship building and servant leadership with respect to P-J fit. 


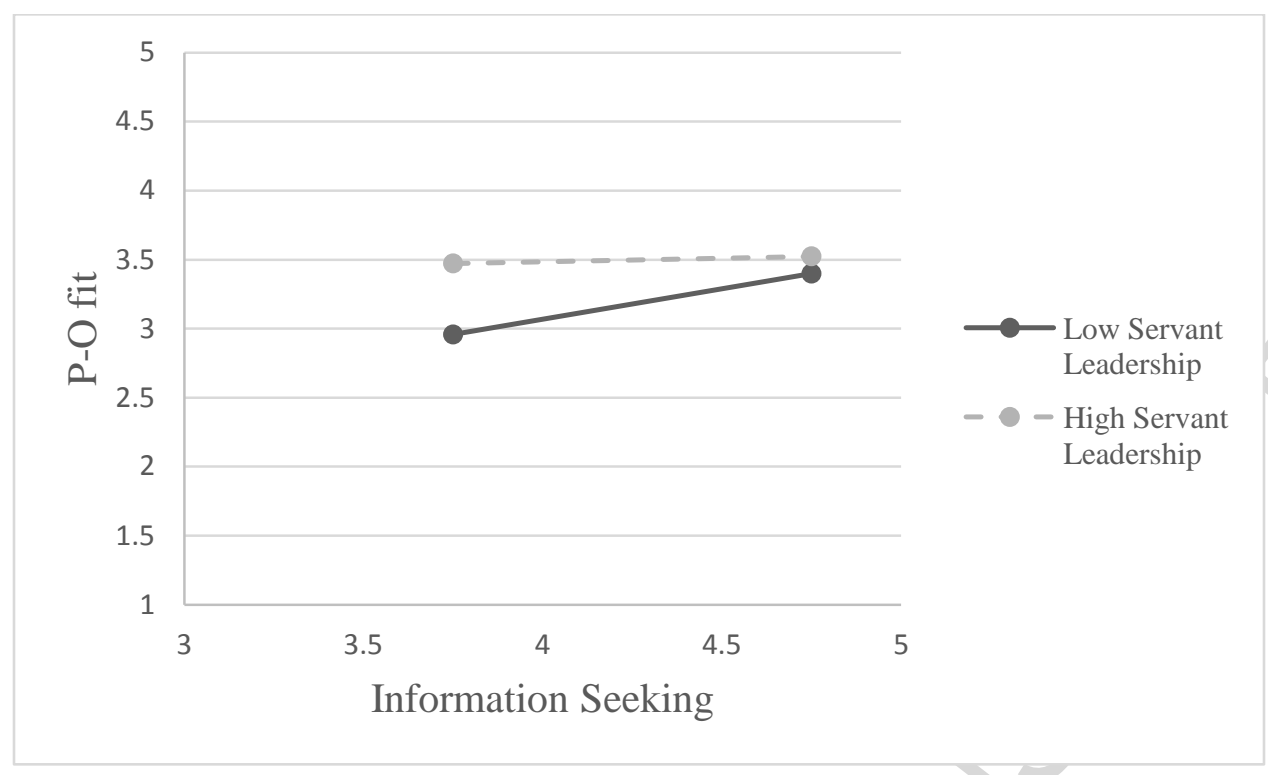

Figure $4 a$. The interaction of information seeking and servant leadership with respect to P-O fit.

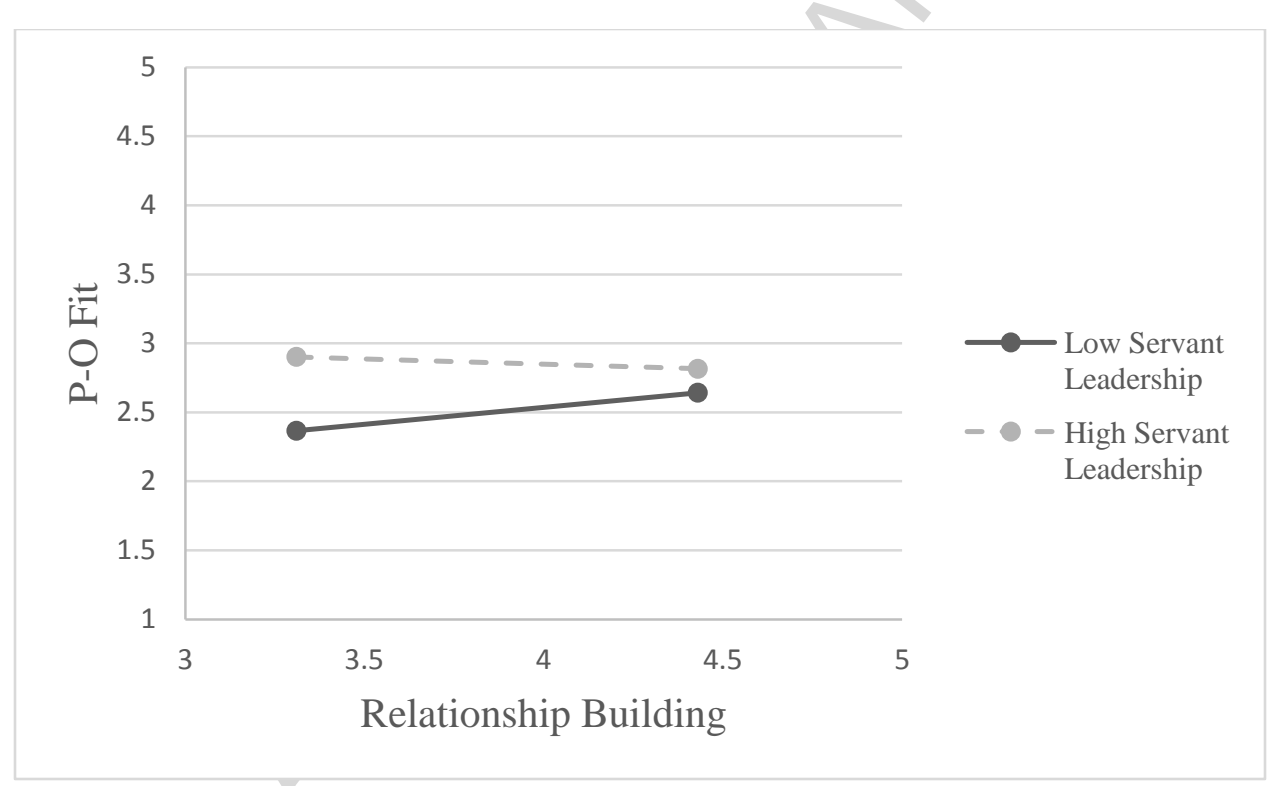

Figure $4 b$. The interaction of relationship building and servant leadership with respect to P-O fit. 


\section{Highlights}

- Across their first six months on the job, new organizational members played an active role in their own adjustment.

- Information seeking and general socialization relate to job satisfaction, person-job fit, and personorganization fit.

- Servant leadership served as an important contextual boundary condition of these relationships. 